Primary Research Paper

\title{
Benthic diatoms as indicators of eutrophication in tropical streams
}

\author{
Brent J. Bellinger ${ }^{1} *$, Christine Cocquyt ${ }^{2} \&$ Catherine M. O'Reilly $^{3}$ \\ ${ }^{1}$ Department of Biological Sciences, Michigan Technological University, Houghton, MI, 49931, USA \\ ${ }^{2}$ National Botanic Garden of Belgium, Meise and Department of Biology, Ghent University, Ghent, Belgium \\ ${ }^{3}$ Department of Biology, Bard College, Annandale-on-Hudson, NY, 12504, USA \\ (*Author for correspondence: E-mail: bjbellin@mtu.edu)
}

Received 04 January 2006; in revised form 07 June 2006; accepted 11 June 2006; published online 30 September 2006

Key words: diatoms, Trophic Diatom Index (TDI), Lake Tanganyika, streams, eutrophication, algae

\begin{abstract}
Diatoms are frequently used as indicators of eutrophication in temperate systems, but little is known about their application to impacted African tropical systems. Five streams located within Gombe Stream National Park and five streams supporting human settlements draining into Lake Tanganyika, East Africa, were investigated for species composition, richness and diversity of epilithic algae. In addition, a trophic diatom index (TDI) developed for monitoring European rivers was applied to these tropical systems. 54 specific and infraspecific diatom taxa representing 20 genera were identified for all sites with Achnanthes s.l., Gomphonema and Navicula s.l. being the most common genera. Species richness varied between 10 and 21 in disturbed streams and 13 and 19 in undisturbed streams. Nutrients were significantly enriched in streams draining the deforested watersheds but indices of diversity and evenness (Shannon H, J and Simpson-Yule D, E) did not show any significant differences between streams in forested and deforested watersheds. Significant differences were observed between pooled data for the TDI between forested and deforested watersheds. Analysis of percent pollution tolerant diatom taxa indicates that organic pollution of streams in deforested watersheds may be contributing to eutrophication. This study shows that African diatoms, cosmopolitan or resembling well-known North American and European taxa, allows for trophic indices tailored to the autecological preferences of species to be applied to new regions, although intensive studies on these African taxa will lead to more accurate results. Measures of species-richness and diversity, historically used to describe the state of an ecosystem, may not be suitable to evaluate streams which are not grossly polluted.
\end{abstract}

\section{Introduction}

Increasing anthropogenic influence in watersheds has led researchers to develop bio-monitoring schemes that can rapidly assess the status of aquatic systems (Kelly \& Whitton, 1998). Indices to assess environmental conditions have incorporated fish, macrophytes, invertebrates and algae (Round, 1991; Kelly \& Whitton, 1998; Jarvie et al., 2002;
Soininen \& Könönen, 2004). From the algae, diatoms have been the primary focus of monitoring studies due to their rapid assemblage response to stress, existing knowledge of the narrow tolerance ranges for a large number of species (Descy, 1979; Kelly \& Whitton, 1995; Potapova et al., 2004), and the persistence of frustules in sediments for historical reconstruction (Round, 1991). Diatoms are widely distributed with many cosmopolitan species, 
enabling cross-system comparisons to be readily made (Kelly \& Whitton, 1998; Cocquyt, 1998; Taylor et al., 2005).

Studies have investigated the response of diatom communities to a range of environmental variables such as salinity, saprobity, $\mathrm{pH}$, and nutrients (organic and inorganic). These studies score species relative to their autecological tolerances or use community composition indices (species abundance, evenness) to assess disturbance (Kelly et al., 1995; Lobo et al., 1995; Kelly \& Whitton, 1995; Fore \& Grafe, 2002). An example is the Trophic Diatom Index (TDI) which was developed for English streams and rivers (Kelly \& Whitton, 1995; Kelly et al., 2001). Weighted average abundances of species in relation to phosphorus enrichment are utilized in calculating a final score for a diatom assemblage. Lower scores reflect nutrient depleted (oligotrophic) systems, while high scores indicate eutrophication of either organic or inorganic nutrients. The relative significance of organic pollution to a system has been found to be related to the abundance of motile diatom species. These pollution-tolerant taxa are enumerated and the percent present within the assemblage characterizes the significance of organic pollution within a system (Kelly \& Whitton, 1998; Kelly et al., 2001; Jarvie et al., 2002). While the TDI or analogous indices have been applied to systems throughout Australia, Europe, North and South America, and Asia (Prygiel \& Coste, 1993; Lobo et al., 1995; Jüttner et al., 1996; Kelly \& Whitton, 1998; Gómez \& Licursi, 2001; Newall \& Walsh, 2005), comparative work on African systems is limited (Lung'ayia, 2002; de la Rey et al., 2004; Harding et al., 2005; Taylor et al., 2005).

Lake Tanganyika, East African Rift, is a tropical system under increasing anthropogenic impacts (Cohen et al., 1993). Deforestation of the steep shorelines and in the catchments of the tributaries, nutrients inputs from the three major rivers (Rusizi, Malagarasi, Lufubu), and locally from the numerous small catchments all threaten this ecosystem (Cohen et al., 1993). In addition, effects of global warming are being observed in water circulation/mixing patterns further reflected in reduced primary and secondary production within the lake (Verburg et al., 2003; O'Reilly et al., 2003). Along the north-eastern shoreline of
Lake Tanganyika, Gombe Stream National Park remains one of the few forested areas of land in the region. This relatively undisturbed area allows for a direct comparison between streams of similar geomorphology in deforested (inhabited, clear-cut) and forested watersheds that should otherwise contain similar benthic communities.

Extensive research on the benthic and littoral planktonic algal assemblages in the north basin of Lake Tanganyika has previously identified around $70 \%$ of the diatom species as cosmopolitan (i.e. distributed world-wide) and $8 \%$ as endemic to the lake (Cocquyt et al., 1991; Caljon \& Cocquyt, 1992; Cocquyt, 1998; Cocquyt, 1999; Cocquyt, 2000; Cocquyt \& Schram, 2000). More recent lake sampling has identified a few more taxa as endemic to Africa (Cocquyt, 2003; Cocquyt \& Jahn, in press). The present information on the autecology of diatoms in Africa is too scarce to compile an adequate list of the ecological tolerance values, however, application of the specific pollution sensitivity index (SPI) to the diatoms of a South African river showed the reliability of using European nomenclature to assess river water quality (de la Rey et al., 2004). Using the available information about the ecological tolerances of species from other regions, diatoms may be useful indicators of disturbance in this tropical system.

It was the goal of this investigation to sample and identify the benthic algal assemblages of tributaries from forested and deforested watersheds and to apply traditional assemblage assessment parameters (i.e. species abundance and evenness) to examine the effects of deforestation on diatom assemblage structure. In addition, given the cosmopolitan nature of the diatom assemblages, the Trophic Diatom Index was applied to assess whether it is possible to apply this widely used index to tropical systems.

\section{Methods}

Sites

Ten streams draining into the northeastern side of Lake Tanganyika, Tanzania were sampled between July 14 and July 28, 2003 (Fig. 1). Five streams drained deforested watersheds containing small villages. The other five were located within 


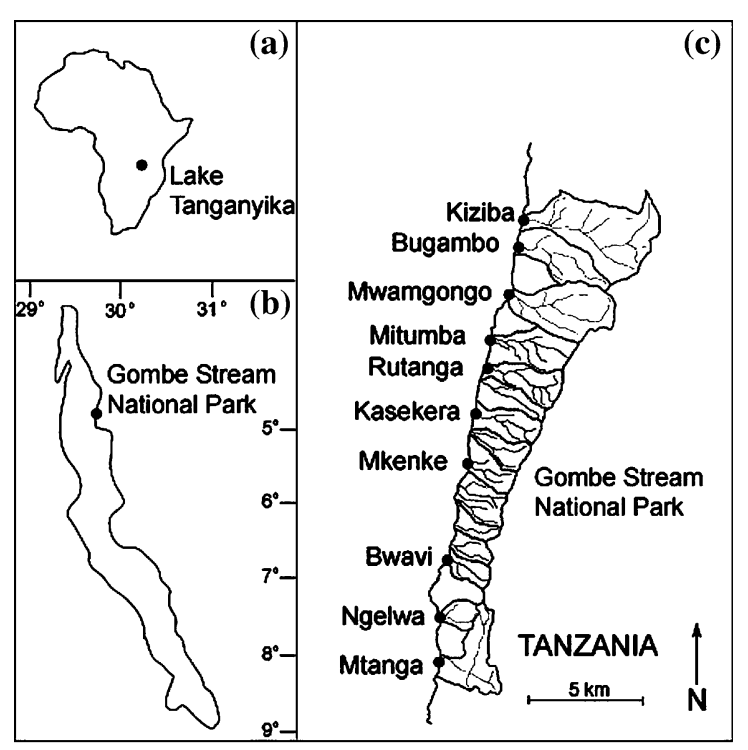

Figure 1. Location of streams sampled along the northeast coast of Lake Tanganyika. (a) Location of Lake Tanganyika in Africa; (b) Location of Gombe Stream National Park on Lake Tanganyika; (c) Location of streams sampled within and outside of Gombe Stream National Park.

Gombe Stream National Park with predominantly undisturbed, forested watersheds. During the dry season (May-October), ground water discharge maintains flow within the streams. The streams are small second or third order systems no more than $3 \mathrm{~m}$ wide and less than $1 \mathrm{~m}$ deep. The last 5-20 m of the stream runs across a cobble beach before entering the lake.

\section{Water chemistry}

Three sites were sampled from each stream within a $25 \mathrm{~m}$ reach. The first site was located on the beach upstream from the stream's outlet to the lake, the second site was $10-15 \mathrm{~m}$ upstream, and a third site was $25 \mathrm{~m}$ upstream from the first site. At each site, physical (stream width, depth, temperature) and chemical (dissolved oxygen (D.O.), conductivity, and $\mathrm{pH}$ ) data were collected using a YSI 556 multiprobe. Water samples were collected for later chemical analyses. Field sampling for physical and chemical parameters was repeated at each stream within 3 weeks. Data from both sampling periods and from each site within a stream were pooled $(n=6)$ due to small differences between sites over the sampling period. Water samples were collected and stored for 1 to
2 days in acid washed Nalgene containers on ice. Unfiltered water was tested for alkalinity using the Hach phenolphthalein and sulfuric acid method. Other samples were filtered through pre-combusted Whatman $(\mathrm{GF} / \mathrm{F})$ filters in the field and analyzed in the lab using Hach reagents and standard methods to measure soluble reactive phosphorus (SRP), (molybdenum blue method); nitrate $\left(\mathrm{NO}_{3}^{-}\right)$(cadmium reduction method); and silica (silicomolybdate method) (www.hach.com).

\section{Algae collection and identification}

Epilithic algal assemblages were collected from each stream at two sites that had similar substrates and flow rates. The first site (site 1) was located on the beach, just upstream from where the stream enters the lake and is identical to the first sampling locality for the water chemistry samples. No tree cover was present at this location for any stream. The second site (site 2) was located approximately $25 \mathrm{~m}$ upstream from the first site, identical to the third sampling locality for the water chemistry samples. In Gombe Stream National Park, this site was always under canopy ( $>70 \%$ cover), while in the deforested watersheds canopy cover was always $<5 \%$. Small cobbles and pebbles dominated the substrate at all sampling locations. The algal sample from upstream (site 2) on Ngelwa River was lost prior to analysis.

At each site a $0.25 \mathrm{~m}^{2}$ quadrant was randomly placed and all the cobbles within this area were collected. In $100 \mathrm{ml}$ of distilled water, rocks were scraped clean of the epilithic algae with a toothbrush. Samples were preserved in $\sim 3 \%$ formalin in the field and the sample volume brought to a final volume of $125 \mathrm{ml}$ with distilled water, returned to the laboratory on ice, and refrigerated until analysis. Samples were thoroughly mixed and one drop of this mixture was put on a slide glass and analyzed with an Olympus CH 30 microscope at a magnification of 400x for soft algae identification to the genus level (Prescott et al., 1978). For diatom species determination, organic matter was removed prior to permanent mounting by adding $2-5 \mathrm{ml}$ of hydrogen peroxide to a 5-10 $\mathrm{ml}$ sub-sample and left in a hot water bath for $\sim 1 \mathrm{~h}$. After rinsing five times with demineralized water, permanent mounts were made with Permount solution (RI 1.52), and labeled. While this may not be the optimal 
mounting solution, it was the only available mountant at the field station of Kigoma. Illustrations of common cosmopolitan, tropical and endemic species are available from the author by request. Counts of at least 400 valves were conducted at $1000 \times$ magnification with an Olympus $\mathrm{CH} 30$ microscope, to ensure the chance of encountering new taxa was minimal (Kelly \& Whitton, 1995). In addition to the work of Cocquyt (1998) on "The Diatoms of the North Basin of Lake Tanganyika" and Gasse (1986) on "East African Diatoms", some more general works were consulted (Hustedt, 1930; Hustedt, 1959; Hustedt, 1961; Krammer \& Lange-Bertalot, 1986; Krammer \& Lange-Bertalot, 1988) for identification of the taxa as well as personal observations by J.C. Stager. Updates to recent nomenclature were addressed according to Jahn \& Kusber (2006) and Kelly et al. (2001). No change in nomenclature resulted in a change in the sensitivity or indicator values used in the calculation of the TDI (see below).

\section{Assemblage descriptions}

Enumerated diatoms were used to calculate several indices to examine the biotic diversity of the streams. The Shannon diversity index $(H)$ and evenness $(J)$ along with the Simpson-Yule Index $(D)$ and evenness $(E)$ were used for within and across site comparisons as well as index comparison (Kempton, 1979). In addition, the Trophic Diatom Index (TDI) developed by Kelly \& Whitton (1995) and revised in Kelly et al. (2001) to include data on new species or to take into account changes in taxonomic naming was applied to species abundance data. Sensitivity values range from 1 to 5 , where 1 indicates species that favor very low nutrients and 5 very high nutrients; and indicator values from 1 to 3 where 3 denotes a species as a good indicator of nutrient sensitivity and 1 a poor indicator (Kelly \& Whitton, 1995; Kelly et al., 2001; Jarvie et al., 2002). Values were originally determined for each diatom species/genus based on the orthophosphate concentrations where taxa are most abundant. The TDI is calculated as:

$$
\mathrm{TDI}=(\mathrm{WMS} * 25)-25
$$

where a Weighted Mean Sensitivity (WMS) value is calculated as:

$$
\mathrm{WMS}=\frac{\sum_{j=1}^{n} a_{j} v_{j} i_{j}}{\sum_{j=1}^{n} a_{j} v_{j}}
$$

where $a_{j}=$ abundance (proportion) of species $\mathrm{j}$ in sample, $\quad v_{j}=$ indicator value (1-3) and $i_{j}=$ pollution sensitivity $(1-5)$ of species $\mathrm{j}$. TDI values range from 0 (indicating very low nutrient concentrations) to 100 (indicating very high nutrient concentrations) (Kelly et al., 2001). The influence of organic pollution was determined by looking at the percent pollution tolerant valves ( $\%$ PTV) by calculating the percentage of motile diatom valves within the assemblages (Kelly et al., 2001). The \% PTV influences the ability of the TDI to accurately assess the impacts of inorganic nutrients on eutrophication (Kelly et al., 2001; Jarvie et al., 2002).

\section{Data analysis}

Student $t$-tests were used to test for significant differences between the forested and deforested TDI means, \% PTV means, water chemistry parameters, Simpson-Yule index and genus and species abundance using SAS JMP IN and Sigma Plot. Water chemistry data were averaged for all sites and sampling dates, giving an $n=6$ per stream. TDI and \% PTV site data were pooled for deforested $(n=9)$ and forested $(n=10)$ watersheds, but also analyzed separately (beach site 1 deforested $(n=5)$ vs. site 1 forested $(n=5)$ and upstream site 2 deforested $(n=4)$ vs. site 2 forested $(n=5)$. A t-test to compare indices was applied to the Shannon diversity index for the deforested and forested streams (Zar, 1998). Observed TDI values were plotted against phosphorus concentration and compared using a t-test against the theoretical TDI values based on the predictive equation of Kelly \& Whitton (1995).

\section{Results}

\section{Differences in stream chemistry}

Table 1 summarizes water chemistry data for each stream. Physical characteristics were similar with respect to width and depth except for the deforested streams Bugambo and Kiziba where stream 


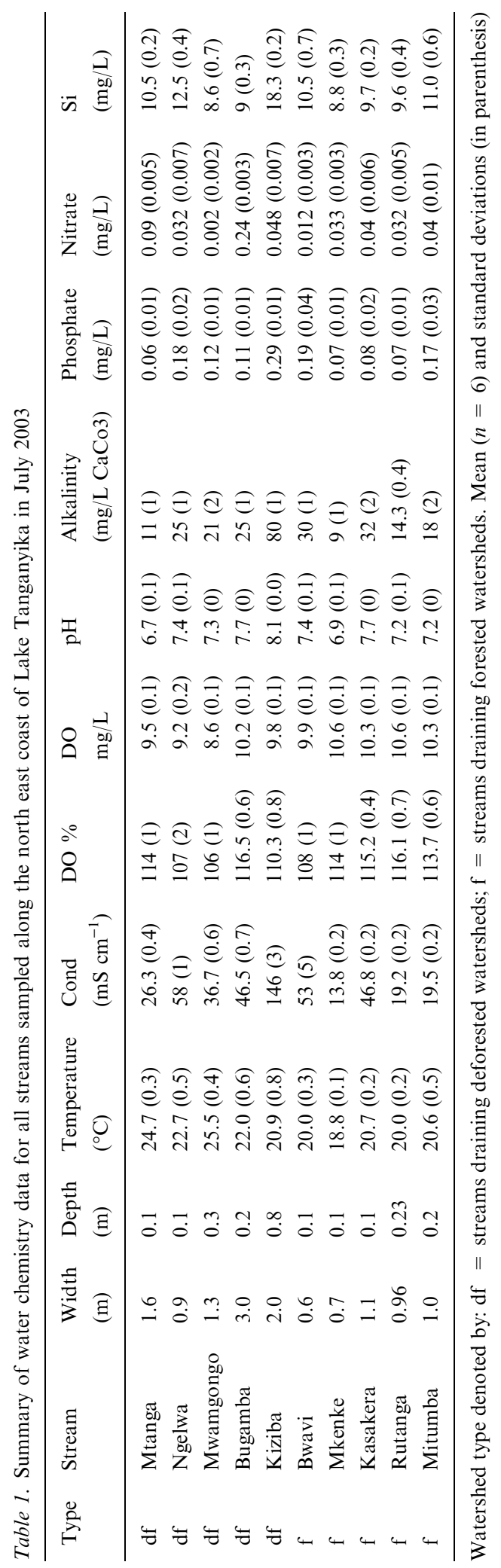


bank erosion was evident, increasing stream width. Water temperatures in streams from deforested watersheds were significantly warmer compared with streams draining forested watershed $(p<0.001)$. Conductivity was significantly higher in deforested streams $(p<0.01)$, even when Kiziba with its high values was excluded $(p<0.01)$ (Table 1). Dissolved oxygen was higher in forested streams, both in terms of concentration $(p<0.01)$ and as a percentage $(p<0.001)$. $\mathrm{pH}$ did not differ significantly. Alkalinity was significantly higher in deforested streams only when Kiziba was included $(p<0.05)$. In deforested streams, phosphorus (SRP) was close to being significantly higher $(p<0.07)$, nitrate was significantly higher $(p<0.01)$, and silica was also significantly higher $(p<0.01)$ (Table 1).

\section{Differences in total algal abundance}

A total of 54 specific and infraspecific diatom taxa representing 20 genera were observed in all streams analyzed. Significant differences were observed between the total number of genera (soft algae and diatoms) between the deforested and forested streams $(p<0.01)$ with the deforested watersheds having significantly more genera present (Tables 2 and 3). In all cases the observed number of diatom genera was significantly greater than that of the soft algae $(p<0.001)$ (Tables 2 and 3).
Differences in the soft algal composition between the forested and deforested sites were observed. At all sites, filamentous green algae were present, typically Cladophora species. In addition, deforested streams contained blue-green soft algae indicative of eutrophication and that may produce toxins, taste and odor problems including taxa belonging to the genera Lyngbya, Oscillatoria and Gloeocystis. The streams located within Gombe National Park had fewer filamentous green and blue-green algae and no toxic, taste or odor causing genera.

\section{Diatom composition}

While many species were found in the streams from all sites, relative abundances indicate differences in diatom assemblages. A full list of diatom taxa present in deforested and forested watersheds can be found in the online Appendices. For deforested streams, relative abundances were greatest for Gomphonema parvulum Kütz, Navicula cf. erifuga L.-B., and Nitzschia palea (Kütz.) W. Smith which were found in all systems and codominated with Achnanthes species. Achnanthes sp. 1 abundances tended to be greater at station 1 (Fig. 2a). A number of taxa showed spatial variability, increasing in relative abundances in more northern streams from the study area (Fig. 2). These include Cocconeis placentula var. euglypta (Ehr.) Grun., Encyonema minutum (Hilse) Mann

Table 2. Summary of algal communities from streams within deforested watersheds along the northeast coast of Tanzania in July 2003

\begin{tabular}{|c|c|c|c|c|c|c|c|c|c|}
\hline & \multicolumn{2}{|c|}{ Mtanga } & \multirow{2}{*}{$\begin{array}{l}\text { Ngelwa } \\
1\end{array}$} & \multicolumn{2}{|c|}{ Mwamgongo } & \multicolumn{2}{|c|}{ Bugamba } & \multicolumn{2}{|c|}{ Kiziba } \\
\hline & 1 & 2 & & 1 & 2 & 1 & 2 & 1 & 2 \\
\hline Soft algae genera & 8 & 7 & 5 & 3 & 4 & 6 & 5 & 4 & 7 \\
\hline Diatom genera & 8 & 8 & 7 & 7 & 9 & 11 & 11 & 7 & 10 \\
\hline Diatom species & 10 & 10 & 12 & 12 & 17 & 20 & 19 & 17 & 21 \\
\hline Total genera & 16 & 15 & 12 & 10 & 13 & 17 & 16 & 11 & 17 \\
\hline \multicolumn{10}{|l|}{ Diatoms } \\
\hline Shannon $(\mathrm{H})$ & 0.61 & 0.64 & 0.94 & 0.81 & 0.90 & 0.97 & 1.02 & 1.03 & 1.13 \\
\hline Shannon Evenness (J) & 0.61 & 0.64 & 0.87 & 0.75 & 0.73 & 0.75 & 0.80 & 0.84 & 0.85 \\
\hline Simpson-Yule (D) & 3.34 & 3.63 & 7.26 & 4.82 & 6.19 & 6.76 & 7.76 & 8.57 & 10.99 \\
\hline Simpson-Yule Evenness (E) & 0.33 & 0.36 & 0.61 & 0.40 & 0.36 & 0.34 & 0.41 & 0.50 & 0.52 \\
\hline TDI & 76 & 90 & 80 & 77 & 75 & 80 & 84 & 78 & 76 \\
\hline$\%$ PTV & 43 & 39 & 45 & 45 & 42 & 29 & 32 & 28 & 32 \\
\hline
\end{tabular}

Site 1 (1) located on the beach near the stream outlet, Site 2 (2) located $25 \mathrm{~m}$ upstream from beach site 
Table 3. Summary of algal communities from streams draining forested watersheds of Gombe National Park, Lake Tanganyika, sampled in July 2003

\begin{tabular}{|c|c|c|c|c|c|c|c|c|c|c|}
\hline & \multicolumn{2}{|l|}{ Bwavi } & \multicolumn{2}{|c|}{ Mkenke } & \multicolumn{2}{|c|}{ Kasekera } & \multicolumn{2}{|c|}{ Rutanga } & \multicolumn{2}{|c|}{ Mitumba } \\
\hline & 1 & 2 & 1 & 2 & 1 & 2 & 1 & 2 & 1 & 2 \\
\hline Soft algae genera & 5 & 3 & 1 & 1 & 3 & 1 & 3 & 1 & 2 & 2 \\
\hline Diatom genera & 9 & 8 & 6 & 6 & 8 & 9 & 7 & 8 & 9 & 7 \\
\hline Diatom species & 13 & 17 & 17 & 14 & 19 & 19 & 18 & 16 & 18 & 17 \\
\hline Total genera & 14 & 11 & 7 & 7 & 11 & 10 & 10 & 9 & 11 & 9 \\
\hline \multicolumn{11}{|l|}{ Diatoms } \\
\hline Shannon $(\mathrm{H})$ & 0.65 & 1.03 & 1.02 & 0.94 & 0.85 & 0.88 & 0.80 & 0.93 & 0.95 & 0.97 \\
\hline Shannon Evenness (J) & 0.59 & 0.83 & 0.83 & 0.82 & 0.67 & 0.69 & 0.64 & 0.77 & 0.76 & 0.79 \\
\hline Simpson-Yule (D) & 3.00 & 9.13 & 8.11 & 7.17 & 4.76 & 4.31 & 4.02 & 6.34 & 5.87 & 6.58 \\
\hline Simpson-Yule Evenness (E) & 0.23 & 0.54 & 0.48 & 0.51 & 0.25 & 0.23 & 0.22 & 0.40 & 0.33 & 0.39 \\
\hline TDI & 82 & 74 & 82 & 61 & 64 & 64 & 72 & 59 & 60 & 56 \\
\hline$\%$ PTV & 59 & 38 & 32 & 7 & 23 & 19 & 51 & 24 & 14 & 8 \\
\hline
\end{tabular}

Site 1 (1) located on the beach near the stream outlet, Site 2 (2) located $25 \mathrm{~m}$ upstream from beach site

(previously Cymbella minuta Hilse), Achnanthes lanceolata var. rostrata Hust. and Amphora copulate (Kütz) Schoeman et R.E.M. Archibald (see supplementary Fig. $2^{1}$ ).

For forested watersheds, diatom assemblages contained similar species to those in deforested watersheds, but typically in lower abundances (Fig. 2, see Electronic Supplementary Material). An exception is the assemblage from the forested Bwavi stream where Nitzschia palea and Gomphonema parvulum dominated along with Achnanthes sp. 1. In all other streams within forested watersheds, Achnanthes sp.1 and Achnanthes sp. 2 dominated, most notably at the upstream site under forest canopy (Fig. 2, see Electronic Supplementary Material). While species assemblages were more uniform in species abundances (with the exception of Achnanthes spp.), a few species showed local assemblage dominance including Gomphonema clevei Fricke (Bwavi, Kasakera, and Mitumba), Navicula cf. erifuga (Rutanga), and Navicula cf. cryptocephala Kütz (Kasakera).

\section{Diversity indices}

Standard diversity indices did not indicate significant differences in diatoms assemblages between

\footnotetext{
1 Electronic Supplementary Material is available for this article at http://dx.doi.org/10.1007/s10750-0060262-5 and is accessible for authorised users.
}

forested and deforested streams. There was no significant difference in diatom species richness between deforested $(15.33 \pm 1.11)$ (mean \pm standard deviation) and forested watersheds $(16.80 \pm 1.05) \quad(p=0.22) \quad$ (Tables 2 and 3). Assessing biological diversity using the Shannon diversity $(H)$ and Simpson-Yule $(D)$ did not yield significant differences between forested and deforested watersheds $(p=0.99$ and $p=0.51$, respectively). Mean values for the Shannon index were $0.89 \pm 0.18$ for streams from deforested watersheds and $0.90 \pm 0.11$ from forested watersheds. Simpson-Yule values were $6.59 \pm 0.73$ in the deforested streams and $5.93 \pm 0.69$ in the forested streams (Tables 2 and 3).

\section{Indicator genera}

Diatom species composition within forested and deforested watersheds showed differences with respect to the abundance of a number of eutrophic indicator genera (Fig. 2). Three genera tolerant to eutrophication, Amphora, Encyonema, and Achnanthes s.l. pro parte were found almost exclusively in the deforested streams (Fig. 2a, b, see Electronic Supplementary Material) (Kelly et al., 2001). Nitzschia palea is typical of phosphate enriched or organically polluted waters (Jüttner et al., 1996; Gómez \& Licursi, 2001; Fore $\&$ Grafe, 2002) and was found in greatest proportions in the deforested streams (Fig. 2c), but 

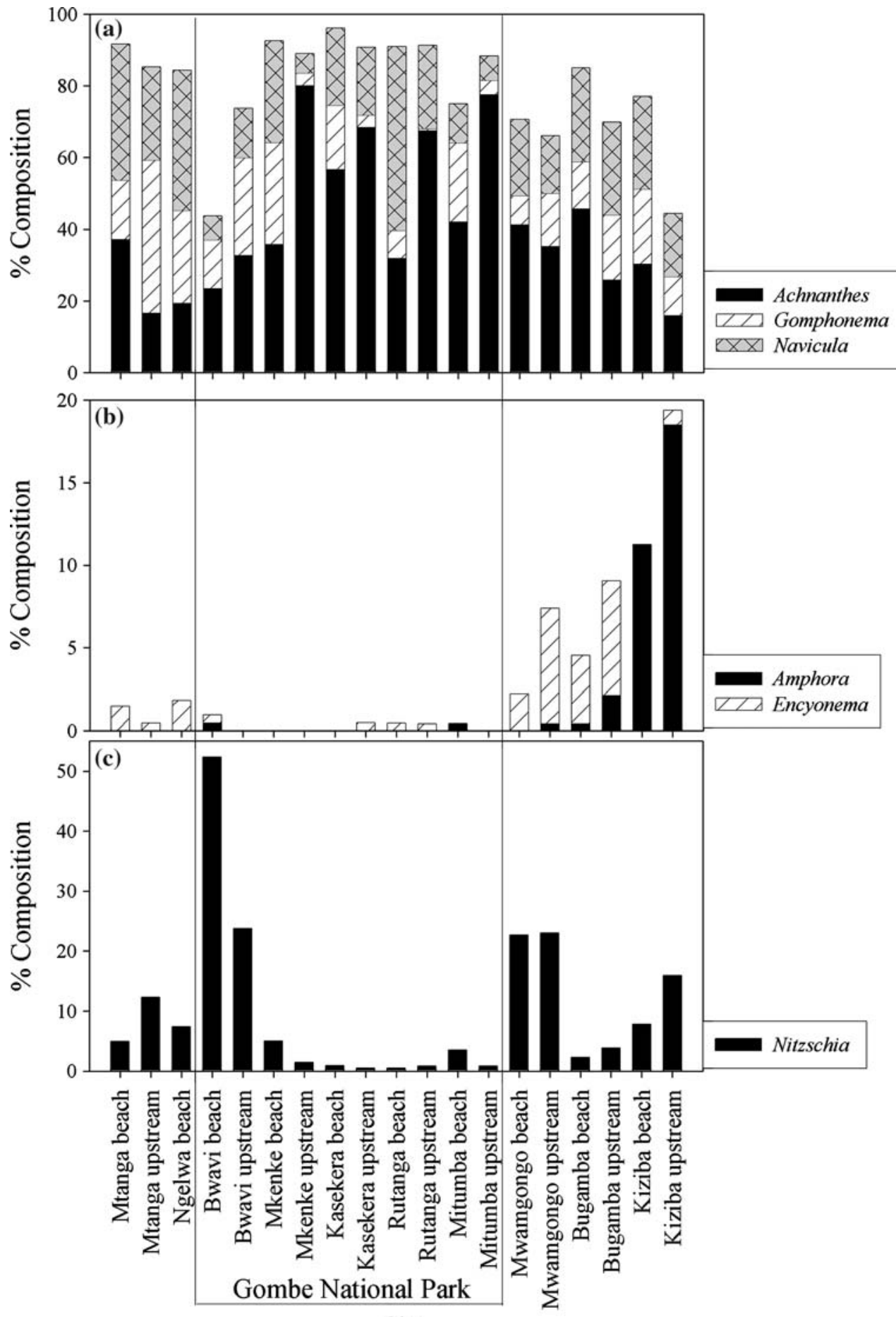

Site

Figure 2. Distribution of select diatom genera for beach and upstream sites. Streams are arranged from south to north, along the Tanzanian coast (refer to Fig. 1). (a) Relative abundance of the three most common genera, indicative of moderate P-enrichment; (b) Indicators of severe eutrophication and nutrient enrichment; (c) Indicator species of severe P-enrichment. 


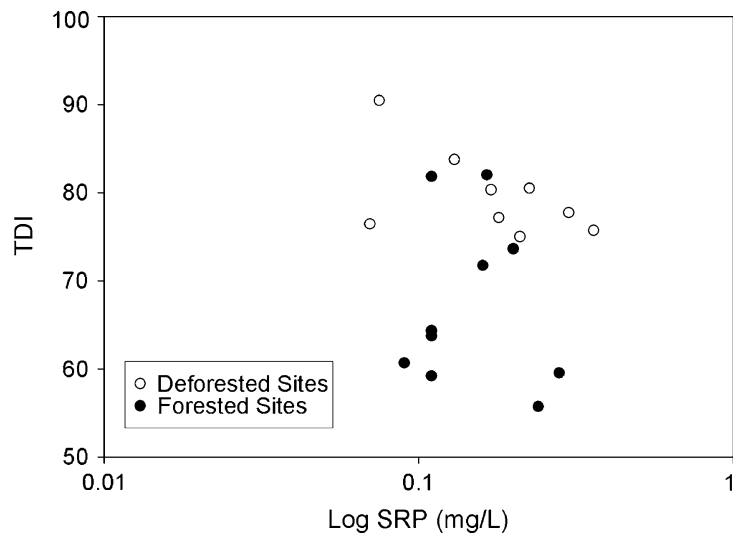

Figure 3. Relationship between trophic diatom index (TDI) and phosphorus (as SRP) for deforested sites (open circles) and forested sites (closed circles).

was also observed to be abundant in the forested Bwavi stream. Taxa that are moderately tolerant to phosphorus enrichment, including species belonging to the genera Achnanthes s.1., Gomphonema and Navicula s.l. were common in all streams (Fig. 2A) (Kelly et al., 2001). Taxa intolerant to high phosphate concentrations (e.g. Rhopalodia, Eunotia) were rare or absent from all stream samples (although when found they were almost exclusively present within forested watersheds at low abundances) (see Electronic Supplementary Material).

\section{Trophic Diatom Index (TDI) and \%PTV}

TDI values for streams in forested watersheds were significantly lower from those of streams in

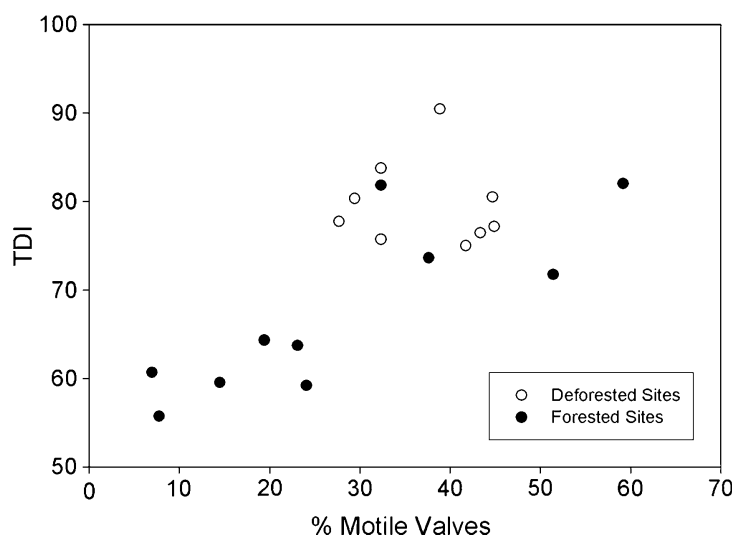

Figure 4. Relationship between \% motile diatom species and observed TDI values for deforested sites (open circles) and forested sites (closed circles). deforested watersheds $(p<0.05)$ (Tables 2 and 3 , Fig. 3). TDI values were $79 \pm 5$ in the deforested systems and $67 \pm 9$ in the forested systems (Tables 2 and 3). When separated by site, TDI values between forested and deforested watersheds were not significantly different at the beach site $(p=0.07)$, but were significantly lower at the upstream site in forested watersheds $(p<0.01)$ (Tables 2 and 3). Phosphorus data from sites were used to calculate TDI values based on the regression equation of Kelly and Whitton (1995) $(\mathrm{WMS}=4.32+0.75 \log \mathrm{SRP})$ and compared with observed results. Deforested watersheds had significantly higher TDI scores compared with predicted values (79 vs. 68$)(p<0.01)$, while those from forested watershed were not significantly different from predicted values $(67$ vs. 67) $(p=0.96)$. The regression equation based on all the data in this study was TDI $=69.63-4.35 \mathrm{log}$ SRP $\left(r^{2}=0.008, p>0.5\right)$, likely due to the limited SRP range encountered in the studied streams.

The $\%$ PTV present within each system averaged $37 \pm 7 \%$ for deforested systems, and $27 \pm 17 \%$ in forested systems (Tables 2 and 3 ) but showed no significant differences $(p=0.14)$. However, when the beach site from Bwavi is removed (due to the high occurrence of Nitzschia palea), significant differences are found $(p<0.05)$. Comparison between forested and deforested watersheds showed no significant differences at the beach site $(p=0.84)$, but a significantly lower $\%$ PTV present $(p<0.05)$ at the upstream site (after the removal of Bwavi). Comparisons of $\%$ PTV between the beach and upstream sites within streams from deforested watersheds found no significant differences $(p=0.27)$ (Table 2$)$, however within forested watersheds the upstream site was found to have a significantly lower percentage of motile diatoms present compared to the beach $(p<0.05)$ (Table 3).

\section{Discussion}

In the watersheds outside of Gombe Stream National Park, deforestation has removed nearly all trees. This has resulted in increased lighting of streams, resulting in significantly higher water temperatures in comparison to forest-covered 
streams within Gombe Stream National Park. Removal of stream bank vegetation has also resulted in bank erosion, widening stream widths and increased siltation within streams. Agricultural use of land is moderate, and streams flowing through settlements are lined with crude water closets which drain almost directly into streams with minimal sediment filtering, representing significant sources of inorganic and organic nutrients. The combination of these effects has caused significantly higher nutrient concentrations in the streams draining deforested watersheds. In addition to the organic pollutants generated from human waste, washing of clothes, dishes and people with soaps and detergents is common and livestock are free to roam through streams, further adding nutrients to these systems. Within Gombe Stream National Park, park and research staff and their families maintain small communities but without deforestation. An explanation for the high nutrient levels observed at Bwavi site is the fact that the park staff tended to more directly utilize the stream (e.g. washing) as opposed to the lake, as was more common at other inhabited sites within Gombe.

From this survey of the algal assemblages in the tributaries to Lake Tanganyika, it appears that taxon (species or genus level) presence/abundance can be a valid and useful tool for inferring local water quality conditions in tropical systems. Observations of cyanobacteria and green algae typical of disturbed, eutrophic systems only in the deforested and populated watersheds help implicate anthropogenic influences as negatively affecting the stream ecosystems. The algae observed could be potentially toxic to livestock and cause taste and odor problems for humans consuming the water. River catchments with reduced forest cover will typically see a downstream increase in nutrient loading, especially with higher intensity land use, shifting the stream algal assemblages from diatoms to filamentous, nutrient-tolerant taxa (e.g. Cladophora and Cyanobacteria) (Biggs, 1996; Kelly \& Whitton, 1998), consistent with observations in this study.

Measures of biodiversity were not useful in this investigation for distinguishing human land perturbations. Metrics of biotic diversity (Simpson-Yule, Shannon diversity index) and species richness in the undisturbed systems were not significantly different between deforested and forested watersheds. Species richness is generally assumed to be greater in undisturbed systems, but it has been shown that minor disturbances may increase diversity (Jüttner et al., 1996; Lowe \& Pan, 1996; Jüttner et al., 2003) or may not show any differences despite heavy human perturbations (Jüttner et al., 1996). A number of criticisms have been leveled against both the Simpson-Yule and Shannon indices. The Shannon diversity index can be strongly influenced by species number while the Simpson-Yule index can be influenced by the proportion of dominant species (Southwood \& Henderson, 2000).

The presence of specific diatom taxa that are indicative of eutrophication in the streams draining deforested watersheds reflect the perturbations occurring throughout their catchments. Taxa tolerant to nutrient enrichment include Amphora copulata, Cocconeis placentula var. euglypta, Encyonema minutum, Gomphonema parvulum and Nitzschia palea (Jüttner et al., 1996; Fore \& Grafe, 2002; Licursi \& Gómez, 2002; Soininen, 2002; Potapova et al., 2004), and were either exclusively found in the deforested watersheds, or were present at greater abundances when compared to the streams from forested watersheds. Nitzschia spp. (mainly $N$. palea) were also found to be abundant at the Gombe National Park Bwavi stream (Fig. 2C, see supplementary Table 2), a system that also had unusually high SRP values (approximately 2-5 times greater than the other undisturbed streams), reinforcing the validity of this species as an indicator of phosphorus-enrichment (Jüttner et al., 1996; Gómez \& Licursi, 2001; Fore \& Grafe, 2002).

In contrast to standard biodiversity metrics, the TDI was a good indicator of water quality and disturbance. Streams draining forested watersheds had less phosphorus, however it does not appear to be a limiting nutrient as molar $\mathrm{N}: \mathrm{P}$ ratios are less than 5 in these streams (Burce \& O'Reilly, 2003; Lomardozzi \& O'Reilly, 2003). Sensitivity values used in the index are based on abundances of certain taxa within a narrow range of phosphorus concentrations. There is concern of comparison of species and autecological preferences between Northern and Southern Hemispheres (Round, 1991), but some of the recent literature suggests the majority of species are cosmopolitan 
and geographical location is not as important in determining species ecological preferences (de la Rey et al., 2004; Taylor et al., 2005), though application of indices may not always yield consistent results (Gómez \& Licursi, 2001). While the majority of species identified here appear to be cosmopolitan, or at least resemble very well North American and European taxa, environmental optima and tolerance ranges may vary in tropical climes, requiring local indices to be developed (Gomá et al., 2004; Lobo et al., 2004). As phosphorus concentrations rise, the TDI value is predicted to increase, an observation confirmed in the streams analyzed, with the impacted streams having a significantly higher TDI value compared with reference streams. Observed TDI values were greater than the theoretical TDI values in deforested watersheds based on the measured phosphorus concentrations likely due to organic enrichment of these streams (see below). The regression equation generated from our data set shows a negative slope, but the effects of inorganic pollution and a limited SRP range are likely confounding these results.

Similar to the TDI, the \%PTV also differed between the forested and deforested streams. The $\%$ PTV within deforested streams was significantly greater compared with forested watersheds (less Bwavi beach). Jarvie et al. (2002), observed marked increases in \% PTV downstream of sewage treatment works (STW's) indicating organic pollutants were contributing significantly to the eutrophic conditions observed. Fore and Grafe (2002) found the number of eutrophic species (\% PTV) were significantly correlated with human disturbance. When Bwavi is removed, the upstream site has significantly lower motile diatoms present both within streams and between deforested and forested watersheds. The increased $\%$ PTV values observed would explain the poor predictive power of the TDI equation within deforested watersheds (Kelly \& Whitton, 1998). Jüttner et al. (2003) found the TDI to be significantly correlated with orthophosphate concentrations when \%PTV values were $<20 \%$. Cumulative effects of nutrients and sediment loading are typically more acute as you move downstream (Minshall et al., 1985), but these effects are exacerbated upstream by the removal of vegetation throughout the watershed and the placement of water closets along the streams banks within disturbed watersheds. Motility is an essential adaptation to prevent burial by siltation, and most motile species tend to display a greater tolerance to organic pollutants (Fore \& Grafe, 2002; Kelly, 2003), both of these situations being present within deforested watersheds.

Although it was not investigated directly in this study, there appeared to be an effect of light on the benthic algal community. Under the forest canopy in Gombe Stream National Park, diatoms dominated the algal community. This is consistent with previous findings that diatoms flourish under lower light intensities (Hill, 1996). On the exposed beaches and throughout the stream reaches of the deforested watersheds, abundant light allowed green algae to better compete with diatoms. For a better mechanistic understanding of how proximate (nutrients, light) and ultimate factors (land use changes, anthropogenic inputs), affect algal species, more controlled studies would need to be conducted (Lowe \& Pan, 1996).

\section{Conclusions}

The present investigation demonstrated that the benthic algal communities and the diatom assemblages reflected watershed manipulations by human activity in tropical streams. The presence of nutrient tolerant algae taxa primarily in impacted streams implicates anthropogenic activities as being detrimental to these streams and also strengthens the usefulness of biological organisms, and especially diatoms, as ecological indicators for water quality monitoring in tropical Africa. To obtain a better understanding of the entire algal assemblage present in the streams, other habitats (sand, mud, tree roots, etc.) throughout the stream reach need to be sampled, but the study of epilithic assemblages was sufficient to indicate eutrophication. The presence of more indicator species in other habitats may be found, reinforcing the relationships observed. It appears from this study that the application of the TDI, developed for temperate streams in the U.K., can also be used for tropical streams. Some modifications to species tolerance scores to account for nitrogen limitation as opposed to phosphorus limitation might be useful for more accurate predictions to 
be made in these tropical systems. In addition, more robust data sets on the autecology of a greater number of organisms will make an index like the TDI a more powerful tool in monitoring eutrophication and recognizing disturbed systems in tropical regions.

\section{Acknowledgements}

This work was funded by US NSF grant \#ATM9619458 (The Nyanza Project). CC is senior researcher on projects financed by the Federal Scientific Policy of Belgium. We also thank D. Lombardozzi for chemical data collected from the sites and J.C. Stager for his help with diatom identification.

\section{References}

Biggs, B. J. F., 1996. Patterns in benthic algae of streams. In Stevenson, R. J., M. L. Bothwell \& R. L. Lowe (eds), Algal Ecology: Freshwater Benthic Ecosystems. Academic Press, San Diego, 31-56.

Burce, A. \& C. M. O'Reilly, 2003. Nutrient limitation in tropical streams of Tanzania. University of Arizona, 53-56.

Caljon, A. G. \& C. Cocquyt, 1992. Diatoms from surface sediments of the northern part of Lake Tanganyika. Hydrobiologia 230: 135-156.

Cocquyt, C., 1998. Diatoms from the northern basin of Lake Tanganyika. Bibliotheca Diatomologica 39: 1-274.

Cocquyt, C., 1999. Seasonal variations of epilithic diatom communities in the northern basin of Lake Tanganyika. Systematics and Geography of Plants 69: 265-273.

Cocquyt, C., 2000. Biogeography and species diversity of diatoms in the Northern basin of Lake Tanganyika. Advances in Ecological Research 31: 125-150.

Cocquyt, C., 2003. Amphora calumeticoides spec. nov (Bacillariophyta), an endemic diatom from Lake Tanganyika. Journal of Great Lakes Research 29: 581-587.

Cocquyt, C., A. G. Caljon \& W. Vyverman, 1991. Seasonal and spatial aspects of phytoplankton along the north-eastern coast of Lake Tanganyika. Annales de Limnologie 27: 215-225.

Cocquyt, C. \& R. Jahn, in press. Surirella nyassae O. Müller, S. malombae O. Müller, S. chepurnovii Cocquyt \& R. Jahn nov. (Bacillanophyta) - typification and variability of three closely related East African diatoms. Nova Hedwiga.

Cocquyt, C. \& D. Schram, 2000. Diatom assemblages in surface sediments along the east coast of Lake Tanganyika. Hydrobiologia 436: 59-71.

Cohen, A. S., R. Bills, C. Cocquyt \& A. G. Caljon, 1993. The impact of sediment pollution on biodiversity in Lake Tanganyika. Conservation Biology 7: 667-677. de la Rey, P. A., J. C. Taylor, A. Laas, L. van Rensburg \& A. Vosloo, 2004. Determining the possible application value of diatoms as indicators of general water quality: A comparison with SASS 5. Water SA 30: 325-332.

Descy, J. P., 1979. A new approach to water quality estimation using diatoms. Nova Hedwigia 64: 305-323.

Fore, L. S. \& C. Grafe, 2002. Using diatoms to assess the biological condition of large rivers in Idaho (USA). Freshwater Biology 47: 2015-2037.

Gasse, F., 1986. East African Diatoms. Taxonomy, ecological distribution. Bibliotheca Diatomologica. 11: 1-202.

Gomá, J., R. Ortiz, J. Cambra \& L. Ector, 2004. Water quality evaluation in Catalonian Mediterranean rivers using epilithic diatoms as bioindicators. Vie et Milieu-Life and Environment 54: 81-90.

Gómez, N. \& M. Licursi, 2001. The Pampean Diatom Index (IDP) for assessment of rivers and streams in Argentina. Aquatic Ecology 35: 173-181.

Harding, W. R., C. G. M. Archibald \& J. C. Taylor, 2005. The relevance of diatoms for water quality assessment in South Africa: A position paper. Water SA 31: 41-46.

Hill, W. R., 1996. Effects of light. In Stevenson, R. J., M. L. Bothwell \& R. L. Lowe (eds), Algal Ecology: Freshwater Benthic Ecosystems. Academic Press, San Diego, 121-148.

Hustedt, F., 1930. Die Kieselalgen. In: Rabenhorst, Kryptogamen-Flora von Deutschland, Österreich und der Schweiz, Teal 1, Leipzig, Acad. Verlag: 1-920.

Hustedt, F., 1959. Die Kieselalgen. In: Rabenhorst, Kryptogamen-Flora von Deutschland, Österreich und der Schweiz, Teal 3, Leipzig, Acad. Verlag: 1-845.

Hustedt, F., 1961. Die Kieselalgen. In: Rabenhorst, Kryptogamen-Flora von Deutschland, Österreich und der Schweiz, Acad. Verlag: 1-816.

Jahn, R. \& W.-H. Kusber (eds), 2006. Algaterra Information System (online). Botanic Garden and Botanical Museum Berlin-Dahlem, FU-Berlin. http://www.algaterra.org

Jarvie, H. P., E. Lycett, C. Neal \& A. Love, 2002. Patterns in nutrient concentrations and biological quality indices across the upper Thames river basin, UK. The Science of the Total Environment 282-283: 263-294.

Jüttner, I., H. Rothfritz \& S. J. Ormerod, 1996. Diatoms as indicators of river quality in the Nepalese Middle Hills with consideration of the effects of habitat-specific sampling. Freshwater Biology 36: 475-486.

Jüttner, I., S. Sharma, B. M. Dahal, S. J. Ormerod, P. J. Chimonides \& E. J. Cox, 2003. Diatoms as indicators of stream quality in the Kathmandu Valley and Middle Hills of Nepal and India. Freshwater Biology 48: 2065-2084.

Kelly, M. G., 2003. Short term dynamics of diatoms in an upland stream and implications for monitoring eutrophication. Environmental Pollution 125: 117-122.

Kelly, M. G., C. Adams, A. C. Graves, J. Jamieson, J. Krokowski, E. Lycett, J. Murray-Bligh, S. Pritchard and c. Wilkins, 2001. The Trophic Diatom Index: A user's manual. E2/TR2. Almondsbury, Bristol: 1-135.

Kelly, M. G., C. J. Penny \& B. A. Whitton, 1995. Comparative performance of benthic diatom indices used to asess river water quality. Hydrobiologia 302: 179-188. 
Kelly, M. G. \& B. A. Whitton, 1995. The trophic diatom index: A new index for monitoring eutrophication in rivers. Journal of Applied Phycology 7: 433-444.

Kelly, M. G. \& B. A. Whitton, 1998. Biological monitoring of eutrophication in rivers. Hydrobiologia 384: 55-67.

Kempton, R. A., 1979. The structure of species abundance and measurement of diversity. Biometrics 35: 307-321.

Krammer, K. \& H. Lange-Bertalot, 1986. Bacillariophyta: Naviculaceae. Stuttgart, Gustav Fischer: 1-876.

Krammer, K. \& H. Lange-Bertalot, 1988. Bacillariophyta: Bacillariaceae, Epithemiaceae, Surirellaceae. Stuttgart, Gustav Fischer: 1-596.

Licursi, M. \& N. Gómez, 2002. Benthic diatoms and some environmental conditions in three lowland streams. Annales de Limnologie 38: 109-118.

Lobo, E. A., V. L. M. Callegaro, G. Hermany, N. Gómez \& L. Ector, 2004. Review of the use of microalgae in South America for monitoring rivers, with special reference to diatoms. Vie et Milieu-Life and Environment 54: 105-114.

Lobo, E. A., K. Katoh \& Y. Aruga, 1995. Response of epilithic diatom assemblages to water pollution in rivers in the Tokyo Metropolitan area, Japan. Freshwater Biology 34: 191-204.

Lomardozzi, D. \& C. M. O'Reilly, 2003. The effects of deforestation on nutrient concentrations in tributaries of Lake Tanganyika. University of Arizona: 47-51.

Lowe, R. L. \& Y. Pan, 1996. Benthic algal communities as biological monitors. In Stevenson, R. J., M. L. Bothwell \& R. L. Lowe (eds), Algal Ecology: Freshwater Benthic Ecosystems. Academic Press, San Diego, 705-739.

Lung'ayia, H. B. O., 2002. Assessment of water quality using diatoms as bio-indicators in catchments of Lake Victoria, Kenya. 1-202. Vrije Universiteit Brussel.

Minshall, G. W., K. W. Cummins, R. C. Petersen, C. E. Cushing, D. A. Bruns, J. R. Sedell \& R. L. Vannote, 1985. Developments in stream ecosystem theory. Canadian Journal of Fisheries and Aquatic Sciences 42: 1045-1055.
Newall, P. \& C. J. Walsh, 2005. Response of epilithic diatom assemblages to urbanization influences. Hydrobiologia 532: 53-67.

O'Reilly, C. M., S. R. Alin, P.-D. Plisnier, A. S. Cohen \& B. A. McKee, 2003. Climate change decreases aquatic ecosystem productivity of Lake Tanganyika, Africa. Nature 424: 766768.

Potapova, M., D. F. Charles, K. C. Ponander \& D. M. Winter, 2004. Quantifying species indicator values for trophic diatom indices: A comparison of approaches. Hydrobiologia 517: 25-41.

Prescott, G. W., J. Bamrick, E. T. Cawley \& W. G. Jaques, 1978. How to know the freshwater algae, McGraw-Hill Science/Engineering/Math.

Prygiel, J. \& M. Coste, 1993. The assessment of water quality in the Artois-Picardie water basin (France) by the use of diatom indices. Hydrobiologia 269/270: 343-349.

Round, F. E., 1991. Diatoms in river water-monitoring studies. Journal of Applied Phycology 3: 129-145.

Soininen, J., 2002. Responses of epilithic diatom communities to environmental gradients in some Finnish rivers. International Review of Hydrobiology 87: 11-24.

Soininen, J. \& K. Könönen, 2004. Comparative study of monitoring South-Finnish rivers and streams using macroinvertebrate and benthic diatom community structure. Aquatic Ecology 38: 63-75.

Southwood, T. R. E., \& P. A. Henderson, 2000. Ecological Methods, Blackwell Science.

Taylor, J. C., W. R. Harding, C. G. M. Archibald \& L. van Rensburg, 2005. Diatoms as indicators of water quality in the Jukskei-Crocodile river system in 1956 and 1957, a reanalysis of diatom count data generated by BJ Cholnoky. Water SA 31: 237-246.

Verburg, P., R. E. Heck \& H. Kling, 2003. Ecological consequences of a century of warming in Lake Tanganyika. Science 301: 505-507.

Zar, J. H., 1998. Biostatistical Analysis, Prentice Hall. 